\title{
MARKETING OPPORTUNITIES OF LOCAL PRODUCTS IN THE CATCHMENT AREA OF CSÍKSZEREDA TOWN
}

\author{
Péter Emóke-Katalin \\ Sapientia University, Faculty of Economics, Socio-Human Sciences and Engineering \\ Department of Economic Sciences, Libertății square no.1, Miercurea Ciuc, 530104 Romania
}

\begin{abstract}
Agriculture plays an outstanding role in Romania, since there are nearly three and a half million small farms operating in the country, accounting for almost $90 \%$ of the total number of farms, and scarcely more than $32 \%$ of the available farm land is cultivated by $35 \%$ of the population. In the settlements found in the catchment area of Csíkszereda, the majority of farms consist of family farms smaller than 5 hectares. The marketing of good quality products made from local raw material by traditional methods contributes to the sustenance of the family farms. Researches show that as a result of the education of the farmers on a local level more and more processed products appear in the markets of Csíkszereda town. Farmers involved in the local market intend to expand their farms on the long run. The respondents consider that "a piece of land can be sold only once", that is why the sustenance of the farm became the main goal of multi-generational effort. Younger farmers are usually more educated and more open to innovation. The vast majority of farmers under 45 find it important to market their products through rural tourism and they are also more eager to join producer groups. Young farmers need to merge traditional methods and knowledge inherited from previous generations with modern opportunities and methods that facilitate production and marketing. Knowledge gained this way makes it possible for small farms to market their products through short supply chains.
\end{abstract}

Keywords: producers, farmers'vision, qualifications, data mining (JEL Classification: Q12,Q13)

\section{INTRODUCTION}

The importance of short supply chains is underscored by the fact that a significant proportion of food today reaches the consumer through such short supply chains (Committee of the Regions, 2011). Supporting and researching local short supply chains from an economic, social, and legal perspective can bring about the innovative and structural boost of the agricultural sector. Local producers participating in short supply chains might market their products at a higher price (Tanase et. al.,2015). The participants in short supply chains - the producers and the consumers- usually have similar demands, as well as comparable cultural expectations and customs. Moreover, they are in close geographical proximity, consequently this type of sales channel offers numerous possibilities for farmers living in the catchment area of Csíkszereda. The aim of the research is to find out how the farmers' archaic and acquired knowledge influences their attitude toward the market and their future economic decisions.

\section{LITERATURE REVIEW}

According to the international literature on short supply chains the popularity of producer markets is on the rise despite high prices practiced by producers manufacturing premium category products (Benedek et. al. 2013). Environmentally conscious consumers pursue this type of purchasing experience, and the direct contact with the producer established this way forms the basis of support for 
local producers. Meeting the changing consumer demands requires above average educations (Juhász, 2012). Analyses focusing on products marketed through short supply chains reveal that the quality parameters of products are regarded to be an important factor - consumers consider that food purchased in local markets are fresher and more delicious. This contributes to the increasing trends in the number of local markets in the United States of America (Brown, A., 2002, Bullock, S., 2000).

It is likely, that the income realized by selling local products through short supply chains remains in the village/settlement because the local producer will probably spend his/her income at home. Research carried out in London proves that small shops and restaurants in the neighborhood of local markets selling local products experienced an increase in their income. The reason lying behind this phenomenon is that customer behavior entails the extension of shopping to small shops in the area. Shop assistants, on their turn, also become consumers of market area services (Taylor et al. 2005). Furthermore, experience with well-established German (Chiemgauer) and Swiss (WIR) local currencies shows that mean of immobile monetary substitute (local currency) increases the amount of money remaining in area and strengthens local economy (Varga, 2016a; Varga, 2017). The possibility for catch up of the micro-regions located mainly on the periphery can lie in short supply chains (OECD,1995). This channel of food provision is expanding even in more developed regions. In today's food production the socioeconomic effects related to food quality become more and more prominent. Such supply chains exercise a more moderate impact on the environment than traditional chains, since the methods of production and distribution are more environmentally friendly, although this varies from product to product. Food kilometers include numerous other factors because apart from noise pollution the probability of accidents and traffic jams is also multiplied. These negative externalities can generate social problems as well.

The participants in short supply chains are usually small farms which can hardly produce any goods for export after providing for local consumers (Szabó, 2017). From the perspective of consumers and producers, short supply chains might be the solution for the pile of problems caused by traditional food industry (Benedek, 2014). The solution is even more optimal

provided that not only the goods but also financial aspect is a "local product", namely, a local currency, and in this way the purchasing power remains on the spot (Varga, 2016b).

\section{Markets today}

In support of local farmers, as a national peculiarity, the Agricultural Chamber of Hargita County organized for the first time in 2009 the exhibition and market of traditional, local goods in Csíkszereda. The goal of this singular initiative was to assure a new marketing opportunity and livelihood for local farmers and producers. The unconcealed ambition of the administrative body operating as an umbrella organization was to encourage consumers to purchase local goods. The overwhelming success of the initiative is reflected by the growing interest in local markets. Maintaining the initial success, a local market takes place in Csíkszereda on the third Saturday of every month, and apart from this, there is a demand for a similar market in Székelyudvarhely on the fourth Saturday. Gradually, the local councils became involved in this initiative, so an increasing number of villages organize their own markets, which leads us to conclude that there is an increasing demand on the part of local producers for this type of local distribution facility. Emboldened by the success of the monthly markets, the initiators started to organize seasonal markets as well (Figure.1.). On these thematic (autumn, spring, Christmas, apiculture) markets and exhibitions the visitors are welcomed with a wider range of products and a two-day cultural program.

Figure.1.

Producers participating on the local market broken down on an annual basis

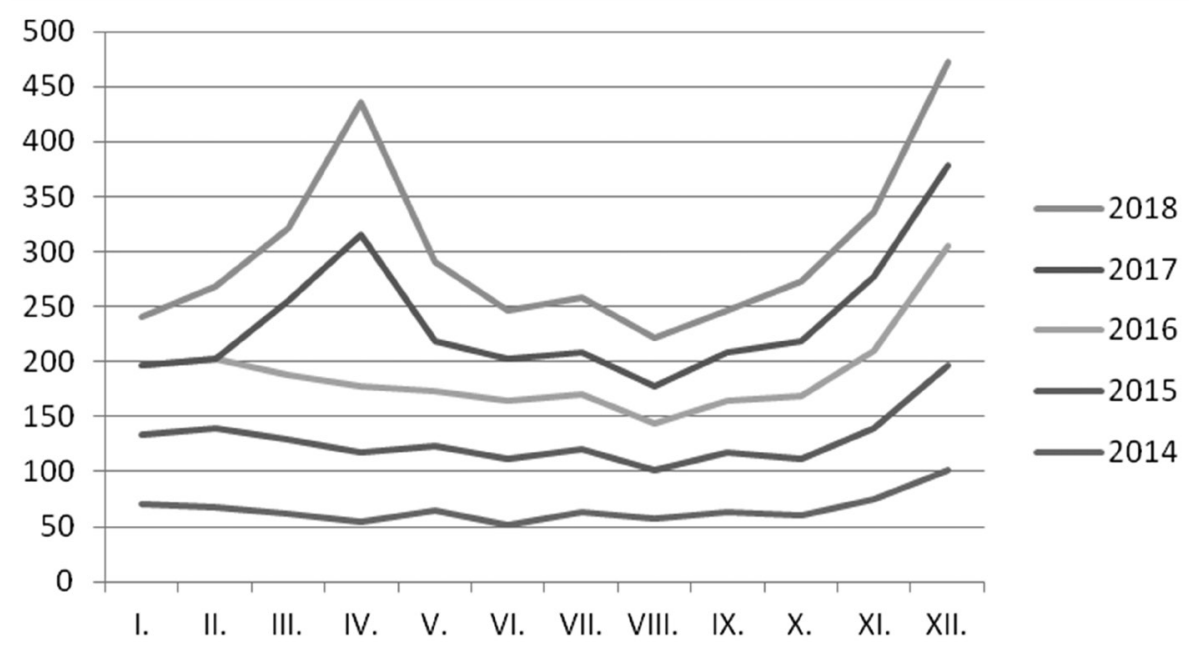

Source: own elaboration based on data provided by Hargita County Council

The success of the monthly and seasonal markets can be measured by the increasing number of farmers present at these events. Eastern and Christmas markets are outstandingly popular, but similar marketing opportunities attract more and more producers as well.

As early as in 2000, the Agricultural Chamber of Hargita County started courses for local farmers where they could acquire methods of processing agricultural products. Graduates of these courses are keen to market their products at the monthly markets. Between the years 2000 and 2018, more than 3400 beekeepers (Figure 2), 760 agronomists, more 
than a hundred bakers, and about 60 dairy processors and cheese makers acquired the secrets of the trade.

Figure.2.

Training courses organized by the Hargita County Council by professions, between the years 2000-2018

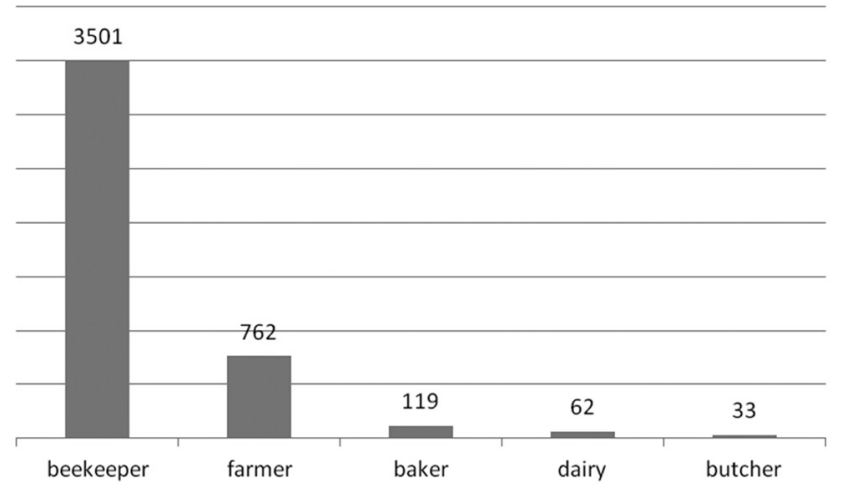

Source: own elaboration based on data provided by Hargita County Council

\section{MATERIAL AND METHODS}

The questionnaire survey was carried out between December 2016 and February 2017. Our respondents were farmers from Hargita county living and producing agricultural products in the catchment area of Csíkszereda, who were involved in marketing their products in local markets. The questionnaire included open-, closed and multiple choice questions. The questions concerning the farms were formulated so that we were able to estimate the family farms of local farmers. Data related to marketing agricultural products were obtained by means of Likert scale, processed with SPSS programme, and the relationships across the variables were scrutinized through cross stable analysis. Data were recorded at a time agreed with the interviewees in person. We worked with a 77-item sample altogether (Péter and Illyés, 2018; Péter and Illyés, 2019).

Our research is characterized by a diversity of data due to the wide-ranging activities of the farmers in Hargita county. The quality and the quantity of the data collected required the use of data mining means because traditional statistical and regression methods proved insufficient (Péter and Illyés; 2018).

A data mining tool extracts information from data. This process is based on statistical methods and/or on Shannon's information theory (Shannon 1948). The extraction of information is carried out by artificial intelligence algorithms. These data cannot be extracted with classical statistical methods. Data mining looks for patterns in the data serving decision support preparation. The oldest classical artificial intelligence method from the toolbox of data mining is the regression method. Data mining is the extrapolation of this method because it not only forecasts numerical values, but it also handles categorization. We use the data mining tool Weka (Hall, 1998)(Witten, 2016) developed at The University of Waikato in New Zeeland.

\section{RESULTS AND DISCUSSION}

The majority of farms in our region are managed by men so there are 65 men and 7 women in our sample. 18 of our interviewees were under the age of 35 , but most of farmers were over 36, out of whom 6 were university graduates, and 51 had secondary school education. At the time of the questionnaire completion, 23 farmers were managing biofarms, and 19 further persons declared that they would rather use ecologically sound technologies.

The level of education was prominent in the research. The majority of the respondents attended higher education, a tiny proportion was secondary school graduates, and only a quarter had primary school education. During the personal interviews, the farmers emphasized the importance of other forms of education which are difficult to categorize, reporting that they missed the final exam at the end of the course. The market presence of human capital at an adequate level and quality is a necessary condition for economic growth (Kelemen and Kollár, 2007)

After clarifying the data, for the sake of transparency we chose to use decision trees, which is a branch of artificial intelligence providing field specialists with interpretable information.

Classifier J48 is a Java script variant of classifier C4.5 (Quinlan, 1993). The categories of belonging to an informal group and that of the processed products were highlighted because respondents frequenting local markets emphasized the importance of these factors. The results of this method also underscore the attitudes of small-holder farmers in our region towards agricultural labour. Our analysis sheds light on the importance of family tradition-based product processing, and the outstanding role played by belonging to different producer and marketing groups in everyday life.

In what follows, we analyze the statistical distribution of attributes considered important by the models.

Figure.3

The category of Informal Cooperation represented by means of reduced attribute clustering

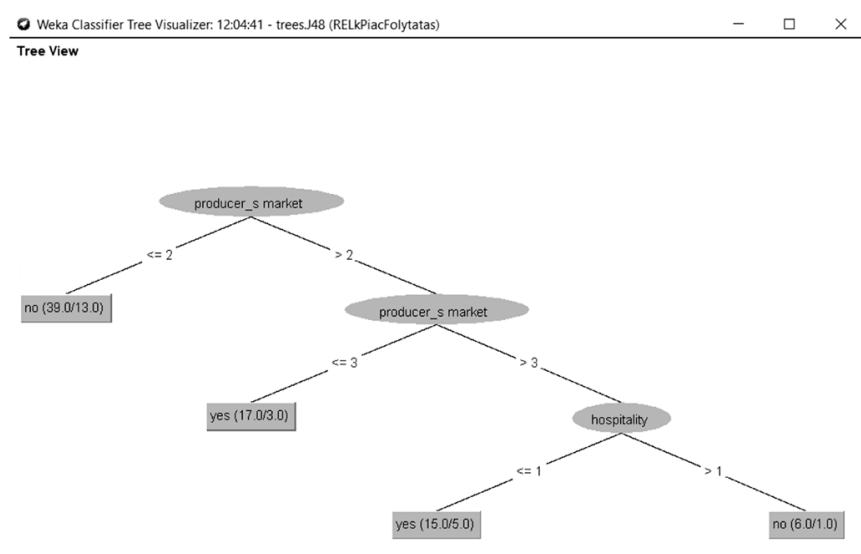

Source: own analysis 
If the informal cooperation is the class attribute, and from the perspective of the respondent the importance of the producer market is at least average ( 2 or 3 ), this indicates that farmers are eager to join different producer groups and are inclined to exploit the advantages of the cooperation. At the same time we can say that if the importance of the producer market is salient for the farmer $(>3)$, and $\mathrm{s} /$ he considers hospitality industry to be important $(>1)$, than s/he tends to rely less on the opportunities offered by informal cooperative groups.

Figure.4

The class is processed food - the emergence of a new activity in the model

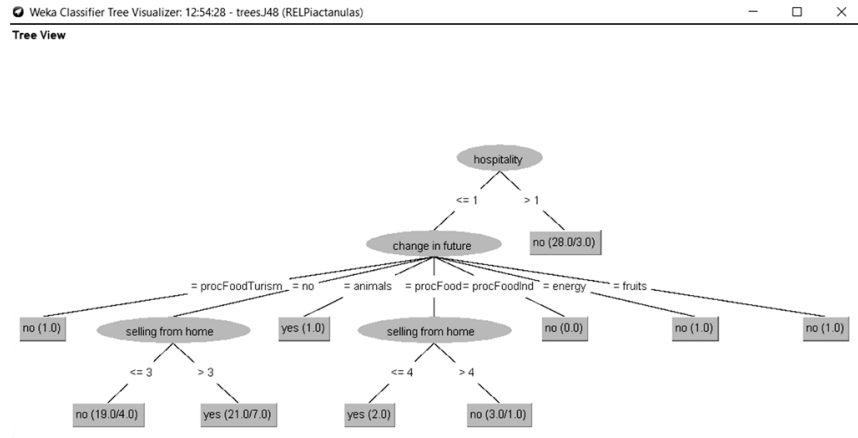

Source: own analysis

From the perspective of processed food, provided that the hospitality industry is important for the farmer, s/he will not focus on processing the product. Furthermore, if hospitality is not a priority for the farmer, his/her decisions related to food processing will be determined by the emerging new activity. If the new activity is food processing, fruit growing and tourism or maybe energy production, this indicates that the farmer has not activated in the processing industry yet. These are small, special cases named outliers requiring a different approach. Another special case is when the farmer shifts to livestock breeding and processes the products right away.

In case the farmer is not considering starting a new activity and he would like to market the products directly from home in the future, and the importance of this project is rated higher than (3) on the Likert scale, then the main activity of the farm will remain food processing. This is the main branch of the tree, the one determining the model the most, including 40 cases with 11 errors (predicting such cases with a $72.5 \%$ precision).

In case the farmer is considering starting food processing in the future, if marketing from home is very important $(>4)$, then processing the products is not so important for him/her. These cases affect only a few individuals (3, out of which 1 is the error), which might be explained by the farmers' prioritising the processing better quality and a wider range of products as a result of the courses attended.

The data of the 2010 Agricultural census sheds light on the features of the Romanian tenure system. More than $98 \%$ of the farmers cultivate a farmland smaller than 10 hectares. The tenure system of our region is mostly characterised by fragmented small-scale farms (Figure 5), a phenomenon reflected in the samples.
$35 \%$ of farmers with higher education cultivate farmlands bigger than 20 hectares, which -considering the geographical endowment and the tenure system possibilities of Hargita county -count as relatively prominent-scale farms. Farmers whose families invested more in training offering a higher level education for their offsprings, cultivate bigger farmlands or they farm more intensively (Nyitrai F. 2001). The economic growth achieved by these respondents is outstanding in our region.

Figure. 5
Distribution of respondents according to size of farmland Source: own analysis

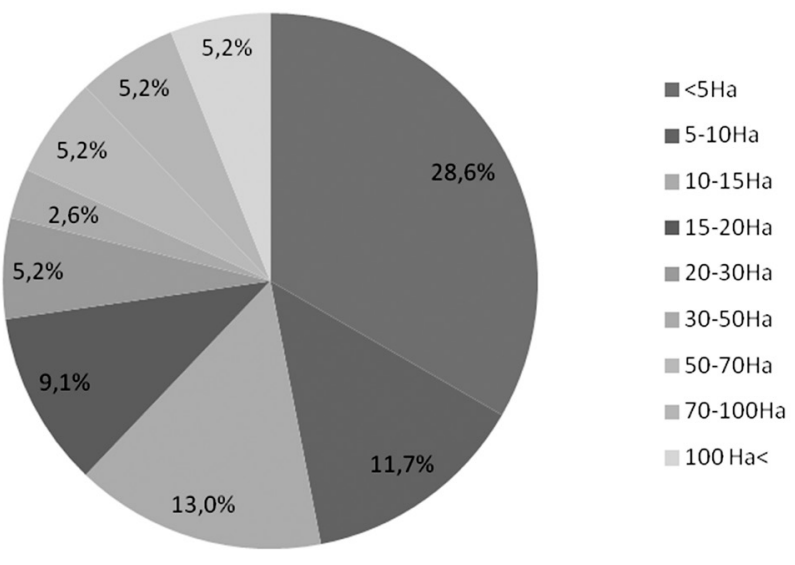

The respondents' vision of the future of economy is very diverse. 21 interviewees would like to expand their farm, 6 of them would rather reduce it, and only one is considering liquidation. Fortunately, most of the farmers, over $62 \%$ of the respondents would like to continue farming, and their goal is to sustain their present farms (Figure 6). Over half of the farmers with primary education are planning to sustain their farms in their present shape and size. None of the farmers with a higher education degree is contemplating the liquidation or the transmission of the farm.

$68,6 \%$ of the farmers with secondary education degree claim that they are aiming at sustaining their farms in its present state, $27,5 \%$ of them is considering expansion, and only $2 \%$ are planning reduction. Some of our respondents aiming at sustaining their farms would like to reduce them, a wish motivated by a great deal of emotional charge and attachment. A very deep appreciation of farmland belonging to the family heirloom impedes liquidation or selling in the farmer's lifetime (Nábrádi et al.,2016). The respondents emphatically voiced the attachment of the family members to the family land, therefore land sale comes into discussion only after great family tragedies, as a last resort. I was glad to hear that none of the farmers belonging to this group would like to liquidate their farm, perhaps they would hand it down.

$22,2 \%$ of the farmers between the age of $18-35$ would like to expand their farms, nearly three quarter of them would like to sustain them at the present level, and only $16,7 \%$ is planning reduction. $34,5 \%$ of the farmers between the age 36-45 wants to expand their farms, although the majority aims at maintaining the present situation. $6,9 \%$ would like 
to reduce, while $3,4 \%$ wants to liquate their farms. Only $20,7 \%$ of the farmers between 46-65 want to expand their farms, in contrast, $65,5 \%$ try to maintain the present situation on every account. $10,3 \%$ want to reduce them, and $3.4 \%$ are considering transmission. This experienced age group is exceptionally attached to their farms, so they don't even take liquidation into account. Farmers falling into the older age group, those over 66 are thinking about expansion.

Figure.6

Distribution of farmers according to future plans

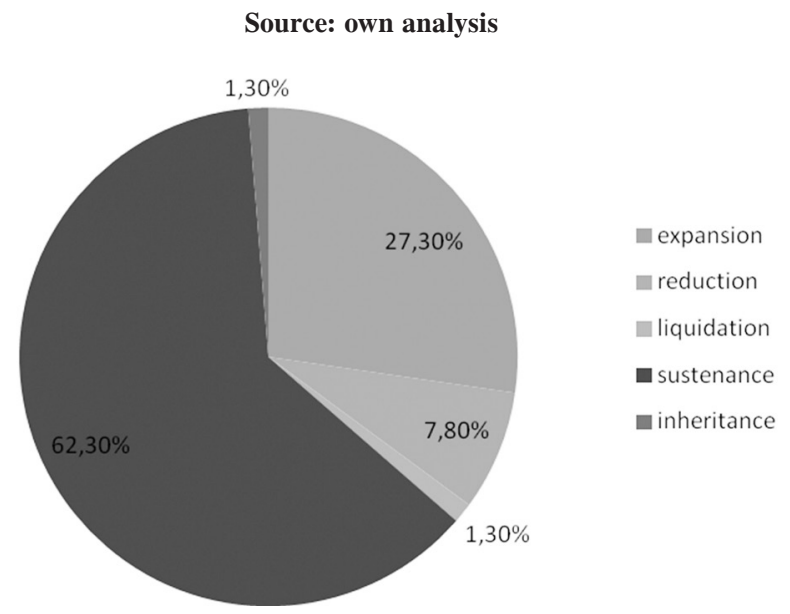

The participants in short supply chains, both the producers and the customers usually have a higher level of education (supposedly the customers' income is also more consistent). It is an advantage for the producer (seller) to possess higher education qualifications, expertise, broad-mindedness, and flexibility when exploring new markets (Benedek et. al.,2013).

The cross table analysis of the respondents' level of education and age reveals that $11 \%$ of young farmers under the age of 35 featuring in the sample possesses higher education, and $61 \%$ have secondary school education. $69 \%$ of the interviewees between 36-45 have secondary-, $6,9 \%$ of them have higher-, and nearly a quarter have primary education.

Just as in any other field of activity, positive models play an important role in agriculture. The ancestors of $74 \%$ of our respondents were also farmers. High level specialist education based on traditional knowledge coupled with adequate financial capital, competence and creativity is the foundation for livelihoods in one's homeland.

Due to the natural assets, the historical and cultural traditions of Csíkszereda town and its surroundings, the tradition of agricultural labour is inherited across generations, and it has become of paramount importance in present-day employment to such an extent that nearly one third of the population is related to this branch. Recognizing the presence of uncertainty factors pertaining to the branch, such as weather changeability and the perishability of the products, the majority of the small-holder farmers from the catchment area of Csíkszereda town were looking for solutions in the establishing of inner coordination (Fertô, 1996). The majority of our respondents do not consider wholesale market to be important because they would not like to share the income. Thus, intermediaries can be avoided and both the producer and the consumer can benefit from the extra profit generated this way (Erudito Zrt., 2012). Stable quality products in demand among the consumers can be easily assured with this method (Kiss, 2018).

Hospitality as a novel marketing channel is becoming more and more attractive for farmers. For $1,3 \%$ of our respondents it is very important, and for 5,2\% it is rather important, while for $13 \%$ it is moderately important, and for the majority it is not or only slightly important (Figure 7).

Figure 7.

The importance of the hospitality industry and rural tourism Source: own analysis, year: 2018

Similarly to most socialist countries, in Romania

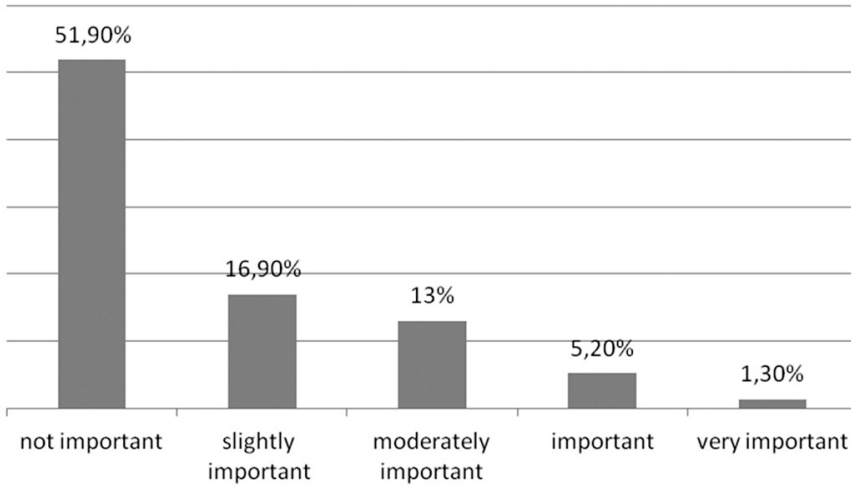

cooperatives were replaced by private farms. In most cases, landowners started farming with insufficient expertise and scant financial resources. This is reflected in the large number of small farms (Figure 8). Nearly $90 \%$ of the declared farms belong to the group of small farms. At the same time, the employers account for more than two thirds of the total number of agriculture workers, and more than $30 \%$ of the livestock is kept in such farms (Kemény and Rácz,2017).

Figure 8.

Distribution according to importance of cooperation Source: own analysis, year: 2018

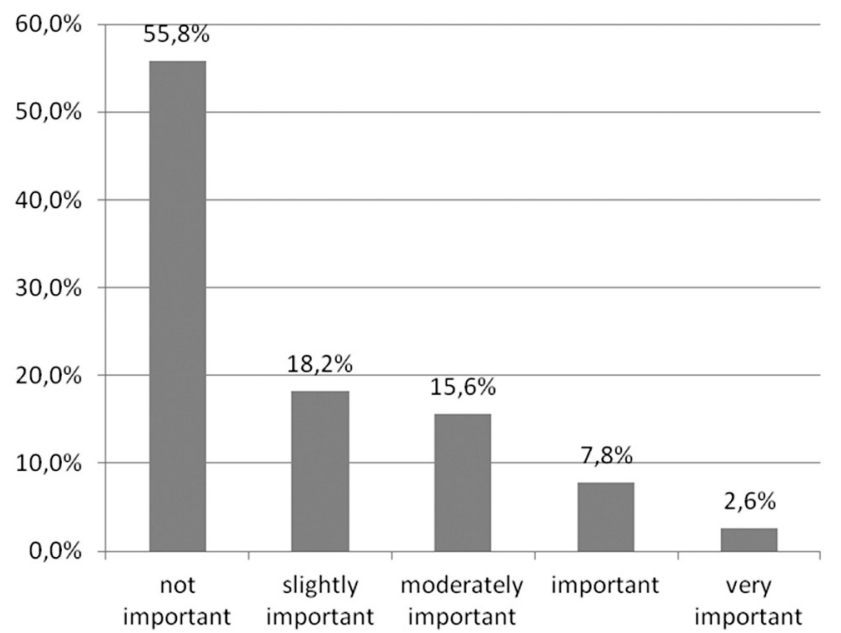


More than half of the respondents were not open to cooperation, $15,6 \%$ considered it moderately important, while $2,6 \%$ thought that some type of cooperation among farmers was very important. Being aware of the anti-cooperatives attitude, we included in our interview a question pertaining to informal cooperation eliciting nearly as many refusals as positive responses. The cross table analysis reveals that the majority of the farmers with a higher education qualification, more than half of those with a secondary level of education, and almost $60 \%$ of those with a primary education level were glad to join a group based on informal cooperation.

Nearly one third of the respondents run their farms with the active contribution of 2 family members, a quarter of them have 3 family members in the business, and in some cases (12\%) there are 4 members of the family. Apart from the family, farmers also appeal to casual workers. $72,7 \%$ of the respondents claimed that they employ casual workers. $73,3 \%$ of the farmers with one active family member would like to sustain their farms, $20 \%$ would like to expand it. $55,2 \%$ of the respondents with two active family members would like to maintain the present shape of their farms. $66,7 \%$ of the farms with three family members, $55,6 \%$ of the farms with four family members, and $75 \%$ of the farms run with the help of five family members are planned to be maintained in the future. The farmers included in our research feel responsible for the family members involved in the business, and they are striving to maintain their farms

\section{CONCLUSION}

We analyzed the future opportunities of the mostly self-sustaining small farms existing in the mountainous agricultural lands of the region. In the present study I looked at producer small-scale farms, which - relying on the available traditions - are eagerly trying to adjust themselves to new consumer demands.

Our research reveals the positive relationship between education and implication in direct marketing channels. Qualified farmers cultivate larger farmlands, and they envisage the continuation of farming in the future. Furthermore, highly qualified farmers are open to different forms of cooperation thanks to their broad-mindedness.

Today, the multitude of small-scale farms characterizes the agricultural branch in Romania including the catchment area of Csíkszereda town. The basic orientation of the respondents' future plans with their farms coincides with the possibilities described in the specialist literature (Thomson and Davidova, 2014), namely expansion, continuation, and sustenance are mentioned as viable perspectives. The cross generational attachment to the farmlands becomes apparent to such an extent that the sustenance future plan does not only include the well-known expansion tendency, but the farmers can also plan their future based on the reduction of the farm.

Looking for the causes of reduction we asked our interviewees to relate the story of their failure, and we came to the conclusion that the farmers would have a purposeful vision entailing economic growth provided they had adequate knowledge and information. If small-scale and food producer farmers realized the importance of life-long learning and they had the opportunity for the constant presence of an organization offering expert support, they could adjust themselves more easily to the economic challenges posed by changing demands, and thus they could also greatly contribute to the future of our region.

\section{REFERENCES}

Benedek Zs, Fertő I, Baráth L, Tóth J (2013): Hogyan kapcsolódhatnak a mezőgazdasági termelők a modern élelmiszerláncokhoz? A rövid ellátási láncokmüködésének hazai sajátosságai: egy empirikus vizsgálat tapasztalatai, Vidékkutatás 2012-2013, NAKVI.

Benedek Zs (2014):: A rövid ellátási láncok hatásai, MTDP-2014/8 MTA közgazdaság- és regionális tudományi Kutatóközpont, Budapest, 2014

Brown A (2002): Farmers Market Research 1940-2000: An Inventory and Review. American, Journal of Alternative Agriculture. http://citeseerx.ist.psu.edu/viewdoc/download?doi=10.1.1.1 99.3976\&rep $=$ rep1\&type $=$ pdf

Bullock S (2000): The Economic Benefits of Farmers Markets: In Friends of The Earth Trust, London, UK.

Erudito Oktatási Zrt. Zárójelentés (2012): A fenntartható müködési programokra vonatkozó nemzeti stratégiák értékelése a zöldség-, gyümölcságazatban címü kutatáshoz kapcsolódó zárójelentés, Budapest, 2012.

Hall M A (1998): Correlation-based Feature Subset Selection for Machine Learning. Hamilton, New Zealand.

Holte RC (1993): Very simple classification rules perform well on most commonly used data sets. Machine Learning. 11:63-91.

Juhász A (2012): A közvetlen értékesítés szerepe és jelentőségei a hazai élelmiszerek piacrajutásában - Élet a modern kiskereskedelmi csatornákon kívül? Agrárgazdasági Tanulmányok, Agrárgazdasági Kutatóintézet, Budapest, 13-15 p.

Juhász A - Szabó D (2013): Piacok jellemzői fogyasztói és termelöi szemmel $=$ The characteristics of marketsfromtheconsumers' and theproducers' point of view. Agrárgazdasági Könyvek. Agrárgazdasági Kutató Intézet, Budapest.

Kelemen N - Kollár B (2007): A tudás hordozói: oktatás és kutatás-fejlesztés. Statisztikai Szemle 85/19.

Kemény G - Rácz K (2017): Mezőgazdasági kisüzemek jellemzői és fejlesztési lehetőségei, AKI,201)

Kiss K (2018): Hagyományos piacok összehasonlító vizsgálata különböző funkciójú településeken, 62.(1)62-75 pp. - (20)Local 
Food Systems - Outlook opinion.

Comittee of the Regions. Retrieved August 06, 2015, from

Nábrádi A, Bárány L, Tobak J(2016): Generációváltás a családi vállalkozásokban In Gazdálkodás 60. (5).427

Nyitrai F (2001): Az oktatás szerepe a gazdaság és társadalom fejlődésében, KSH. Budapest

OECD (1995): Niche Markets as a Rural Development Strategy, OECD, Paris

Shannon C E (1948): A mathematical theory of communication. Bell System Technical Journal, 27, pp. 379-423 and 623-656, July and October 1948

Péter EK - Illyés L(2018): Survive or not to Survive-Farms in short supply chains in Harghita County- In Challenges int he Carpatian Basin, Miercurea Ciuc,2018, p 160-170

Péter EK - Illyés L (2019): A helyi értékesítés szerepe Csíkszereda és vonzáskörzetében, In. Gazdálkodás 2019/3, p.204-2018

Szabó D (2017): Determining the target groups of Hungarians short supply chains based on consumer attitude and socio-demographic factors. Studies in Agricultural Economics 119 (3), pp 115-122.

Quinlan R (1993): C4.5: Programs for Machine Learning. Morgan Kaufmann Publishers, San Mateo, CA.

Tanase L - Brumă I - Sebastian-Doboș S(2015): Contribuția lanțurilor scurte de aprovizionare în dezvoltarea micilor producatori agroalimentari locali. Studiu de caz: Județul Harghita, Institutul de Cercetare pentru Economia Agriculturii şi Dezvoltării Rurale, Bukarest

Thomson K - Davidova S (2014): Economic Aspects of Family Farming in the European Contex, Discussion Paper prepared for presentation at the 88th Annual Conference of the Agricultural Economics Society, Paris.

Taylor J, - Madrick M - Collin S (2005): Trading Places: The Local Economic Impact of Street Produce and Farmer'sMarkets. London Development Agency, London

Witten I - Frank E - Hall M - Pal C(2016): The WEKA Workbench. Online Appendix for "Data Mining: Practical Machine Learning Tools and Techniques", Morgan Kaufmann, Fourth Edition

Varga J (2016a): Helyi pénzek müködésének nemzetközi tapasztalatai. In: Kerekes S. (szerk.) Pénzügyekről másképpen: Fenntarthatóság és közösségi pénzügyek. 249. Budapest. CompLex Wolters Kluwer, pp. 209-234.
Varga J (2016b): A helyi pénz megjelenése és szerepe a gazdaságban. In: Kerekes S. (szerk.) Pénzügyekről másképpen: Fenntarthatóság és közösségi pénzügyek. 249 p. Budapest. CompLex Wolters Kluwerpp. 161-208.

Varga J (2017): A Chiemgauer, mint sikeres helyi pénz működése The operation of succesful local currency, The Chiemgauer. Közép-Európai Közlemények 10:(2 / No. 37) pp. 91-100. 